\title{
Uso de implante intravaginal de progesterona no período transicional de éguas da raça Crioula
}

Rafael dos Santos Bandeira ${ }^{[a]}$, Guilherme Novello ${ }^{[b]}$, Candido Victor Kern ${ }^{[c]}$, GAbriel Victoria Martins ${ }^{[b]}$, Raqueli Teresinha França $^{[b]}$, Fernando Paixão Lisboa ${ }^{[b]}$

\author{
[a] Universidade Estadual Paulista (UNESP), Botucatu, SP, Brasil \\ [b] Universidade de Caxias do Sul (UCS), Caxias do Sul, RS, Brasil \\ [c] Universidade Federal de Pelotas (UFPel), Pelotas, RS, Brasil
}

*Autor correspondente

e-mail: rafa.bandeira@hotmail.com

\section{Resumo}

O uso de implantes intravaginais de progesterona vem sendo uma alternativa para a indução da ciclicidade de éguas em transição. Por mais que ocorra crescimento folicular durante este período, a ovulação não acontece devido aos baixos níveis de LH, hormônio responsável pela maturação folicular e ovulação. 0 objetivo deste trabalho foi avaliar o uso do implante intravaginal de progesterona no período transicional de éguas da raça Crioula. Foram utilizadas seis éguas, que apesar do bom escore corporal, apresentavam sinais de transição no mês de outubro, diferente do observado nos outros animais da propriedade. Os animais foram avaliados através de palpação retal e ultrassonografia, onde observou-se folículos com cerca de $25 \mathrm{~mm}$, ausência de corpo lúteo e edema uterino. 0 dia da aplicação do dispositivo intravaginal (Cronipres ${ }^{\circledR}$, Laboratório Biogénesis) foi considerado o dia 0 (D0), e previamente a sua introdução, retirou-se a corda plástica e foi instilado Terracortril ${ }^{\circledR}$ spray para prevenir uma possível vaginite. A introdução vaginal foi realizada com a mão enluvada. Após sete dias de tratamento, as éguas 2, 3 e 4 não apresentaram folículos maiores do que $30 \mathrm{~mm}$, demonstrando um desenvolvimento folicular discreto comparado às demais. A retirada do implante foi realizada no D9, onde as éguas 1, 5 e 6 apresentaram folículos de 33, 33 e 42 mm, respectivamente. Já as éguas 2, 3 e 4 mantiveram o mesmo padrão folicular. A indução da ovulação foi realizada no D10 para as éguas 5 e 6, e no D11 para a égua 1. A inseminação artificial (IA) foi realizada no dia seguinte à indução, sendo utilizado um total de 1 x 109 espermatozoides móveis. A detecção da ovulação ocorreu 24 horas após a IA. Ao final do tratamento (D9), um novo implante foi utilizado nas éguas que não responderam, sendo as mesmas trocadas para um potreiro com maior disponibilidade de forragem. No entanto, durante o segundo tratamento, em função de problemas de manejo da propriedade, os implantes só foram retirados 
após 12 dias. No dia da retirada foi constatado que as éguas 2 e 3 já haviam ovulado, mesmo com a presença do dispositivo, enquanto a égua 4 apresentou folículo de $38 \mathrm{~mm}$. A ovulação foi induzida no dia seguinte (D13), inseminação no D14 e a ovulação detectada no D15. Dos três animais inseminados no primeiro tratamento, dois emprenharam no primeiro ciclo e um no ciclo subsequente. No segundo tratamento, a égua 4 emprenhou neste procedimento, enquanto as demais foram tratadas com cloprostenol, retornando ao cio em sete dias. Não foram observados casos de vaginite em nenhum dos tratamentos. 0 implante intravaginal eleva os níveis de progesterona fazendo feedback negativo na liberação do LH, o qual fica armazenado na hipófise. Ao final do tratamento, com a retirada do implante, a queda nos níveis de progesterona proporciona a liberação do LH em concentrações suficientes para maturação e ovulação do folículo dominante. Caso o implante seja mantido além do período recomendado, a ovulação pode ocorrer da mesma forma, já que as concentrações de progesterona diminuem, conforme observado em nosso segundo tratamento. Ao final do estudo foi observada uma eficácia de $50 \%$ no primeiro tratamento, sendo necessário o segundo, associado à troca de manejo, para a obtenção de um resultado final de $100 \%$ de retorno à ciclicidade. Através destes achados é possível concluir que a utilização de implante intravaginal de progesterona é eficaz para induzir a ciclicidade quando utilizados em éguas em transição.

Palavras-chave: Implante intravaginal. Progesterona. Ciclicidade. 